\title{
Leukemic Infiltration of Brain
}

National Cancer Institute

\section{Source}

National Cancer Institute. Leukemic Infiltration of Brain. NCI Thesaurus. Code C114944.

A pathologic finding indicating the presence of leukemic cell infiltrates in the brain tissue. 